\title{
建材重防食用ウレタンエラストマー被覆の 性能
}

\section{技術報告}

|/IIIIIIIIIIIIIIIIIIIII

$$
\text { 岸川浩 史*·大北 雅 一*2 }
$$

\section{The Performance of Urethane Elastmer Coating for Steel Construction Materials}

\author{
Hirofumi KISHIKAWA and Masakazu ОкITA
}

\section{Synopsis :}

30 years have passed since steel construction materials were used for base of the marine structures. But their corrosion rate was over the estimation, so development of effective anticorrosive system have been expected.

We examined the performance of 3 kinds of heavy duty coatings, urethane elastmer coating, tar urethane coating and powderd polyethylene coating which is able to be coated in the mill.

Urethane elastmer coating is the best of 3 coatings. It had superior performance balance and especially excellent corrosion resistance because of the primer which could keep adhesion strength in wet condition even if without chromate treatment.

Urethane elastmer coating wasn't damaged for driving test of coated steel sheet pile.

Now, urethane elastmer coated steel construction materials have been widely used for base of marine structures.

Key words : construction materials; sheet pile; sheet pipe pile; heavy duty coating; marine structure; urethane elastmer; tar urethane; powderd polyethylene; corrosion resistance.

\section{1. 緒}

言

我が国に扔いて各種構造物の基礎鋼材として鋼管杭・ 鋼管矢板ならびに鋼矢板が使用されて以来，約 30 年の 年月が経過した。これらの鋼材は，近年のウォーターフ ロント開発志向に伴いその需要が増加しつつある.

しかし，よく知られているように，海洋環境は鋼材に 対し厳しい腐食環境であり，40 年以上の長期耐久性を 要求される港湾海洋構造物での最大の課題は, 鋼材の防 食対策である。従来より種々の防食対策が実施されてき たが，いずれの方法もその防食効果・耐久性ならびに施 工性の面で十分とはいえない。昭和 58 年, 横浜の山下 埠頭において耐用年数 50 年で設計された栈橋が, 鋼管 杭の腐食により 20 年余りで損壞するという事故も発生 しており，効果的な防食対策の開発が強く望まれている.

本報告では形状の複雑な鋼管矢板ならびに鋼矢板に対 してミルコーティング可能な 3 種類の超厚膜型重防食被
覆システムについて検討し, ウレタンエラストマー被覆 が防食被覆として優れた性能を有することを明らかにし た.

\section{2. 重防食被覆の要求性能}

海洋環境の鋼材の腐食においては，海水の飛沫による 濡れと直射日光による乾湿の繰返し, 温度上昇, 十分な 酸素供給などの腐食促進要因が重なる飛沫带1) ならびに マクロセルにより集中腐食 ${ }^{2)}$ を生じる平均干潮面直下の 腐食が激しいことはよく知られている，従来，港湾施設 の設計基準は，腐食速度 $0.3 \mathrm{~mm} / \mathrm{y}$ であるが, 実際には 2 倍以上の腐食速度 ${ }^{3)}$ も報告されており，また，既存海 洋構造物の老朽化が予想以上に激しいことから設計基準 の見直し4) が図られている.

このように耐用年数の長い海洋構造物の防食法として は

( 1 )錆代加算

平成 2 年 11 月 15 日受付 (Received Nov. 15, 1990)

* 住友金属工業(株)鉄鋼技術研究所 (Iron \& Steel Research Laboratories, Sumitomo Metal Industries, Ltd., 1-8 Fuso-cho Amagasaki 660)

*2 住友金属工業(株)未来技術研究所 (Advanced Technology Research Laboratory, Sumitomo Metal Industries, Ltd.) 


\section{( 2 )電気防食 \\ ( 3 )塗装}

などの方法が用いられてきた（1)では上記のような大 きな腐食速度を考え合わせると，経济性・实用性に問題 があり，(2)では最も激しい飛沫带の隼食を防ぐことが できないという問題がある。（3)では従来の夕ールエポ キシなどの現地施工による薄膜被覆では防食性に劣り， 塗替えを必要とするという問題があった。

このため近年はミルコーティングによる 2 $3 \mathrm{~mm} の$ 超厚膜型（重防食）被覆が適用されつつある。この重防 食被覆に要求される主な特性としては，下記の 3 点が考 えられる。

（1）数十年におよぶ長期間，鋼材を上記候食環境から 遮断する防食性能

( 2 )直射日光に含まれている紫外線に対しても長期間 劣化を生じない被膜高分子樹脂の耐久性

( 3 ) 流木などの漂流物による衝撃にも耐える被覆の衝 撃強度

Table 1. Tar urethane coating material.

\begin{tabular}{|c|c|c|}
\hline Item Component & Base resin & Curing agent \\
\hline $\begin{array}{l}\text { 1. Colour } \\
\text { 2. Solvent }\end{array}$ & $\begin{array}{l}\text { Black } \\
\text { No solvent }\end{array}$ & $\begin{array}{l}\text { Dark blown } \\
\text { No solvent }\end{array}$ \\
\hline 3. Composition & $\begin{array}{l}\text { - Polyetherpolyol resin } \\
\text { - Tar } \\
\text { - Pigment }\left(\mathrm{BaSO}_{4}, \mathrm{CaCO}_{3}\right)\end{array}$ & $\begin{array}{l}\text { Polymethylene- } \\
\text { polyphenyl- } \\
\text { polyisocyanate }\end{array}$ \\
\hline $\begin{array}{l}\text { 4. Viscosity } \\
\text { 5. Specific gravity }\end{array}$ & $\begin{array}{l}6140 \mathrm{cps}\left(\text { At } 60^{\circ} \mathrm{C}\right) \\
1.71\end{array}$ & $\begin{array}{l}117 \mathrm{cps}\left(\text { At } 20^{\circ} \mathrm{C}\right) \\
1.23\end{array}$ \\
\hline $\begin{array}{l}\text { 6. Mixture ratio } \\
\text { 7. Pot life } \\
\text { 8. Curing time }\end{array}$ & \multicolumn{2}{|c|}{ 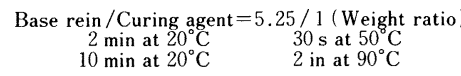 } \\
\hline
\end{tabular}

\section{3. 実 験 方 法}

供試被椱材を Table 1３に示す。タールウレタン及 びウレタンエラストマーは二液混令タイプの常温硬化型 塗料である. 被覆鋼板サンプルは, $150 \times 70 \times 3.2$ の ブラスト鋼板（防錆度 $>\mathrm{Sa} 21 / 2 ）$ を原板とし，スプレー 塗装後常温硬化により作製した。またポりエチレン粉体 については, 低密度ポリエチレンを使用し, 被㠅鋼极开

Table 2. Urethane elastmer coating material.

\begin{tabular}{|c|c|c|}
\hline Item Component & Base resin & Curing agent \\
\hline $\begin{array}{l}\text { 1. Colour } \\
2 \text {. Solvent }\end{array}$ & $\begin{array}{l}\text { Gray } \\
\text { No solvent }\end{array}$ & $\begin{array}{l}\text { Clear } \\
\text { No solvent }\end{array}$ \\
\hline 3. Composition & $\begin{array}{l}\text { Polyesterpolyol- } \\
\text { urethane oligomer } \\
\text { - Pigment } \\
\text { ( } \mathrm{SiO}_{2}, \mathrm{TiO}_{2}, \\
\text { Carbon black) }\end{array}$ & MDI type isocyanate \\
\hline $\begin{array}{l}\text { 4. Viscosity } \\
\text { 5. Specific gravity }\end{array}$ & $\begin{array}{l}1500-2500 \\
\quad \operatorname{cps}\left(\text { At } 25^{\circ} \mathrm{C}\right) \\
1.32\end{array}$ & $\begin{array}{l}150 \sim 450 \mathrm{cps}\left(\text { At } 25^{\circ} \mathrm{C}\right) \\
1.24\end{array}$ \\
\hline $\begin{array}{l}\text { 6. Mixture ratio } \\
\text { 7. Pot life } \\
\text { 8. Curing time }\end{array}$ & \multicolumn{2}{|c|}{$\begin{array}{c}\text { Base rein / Curing agent }=3 / 1 \text { (Weight ratio) } \\
6 \sim 8 \text { min at } 25^{\circ} \mathrm{C} \\
2 \mathrm{~h} \text { at } 90^{\circ} \mathrm{C}\end{array}$} \\
\hline
\end{tabular}

Table 3. Polyethylene powder coating material.

\begin{tabular}{l|l}
\hline \multicolumn{1}{c|}{ Item } & \multicolumn{1}{c}{ Details } \\
\hline $\begin{array}{l}\text { 1. Colour } \\
\text { 2. Composition }\end{array}$ & $\begin{array}{l}\text { Black } \\
\text { - Low density polyethylene } \\
\text { - Buthyl rubber } \\
\text { - Carbon black }\end{array}$ \\
\hline 3. Melting point & $124^{\circ} \mathrm{C}($ By DSC) \\
4. Specific gravity & $0.928 \mathrm{~g} / \mathrm{cm}^{3}$ \\
5. Melt index & $\begin{array}{l}3.1 \mathrm{~g} / 10 \mathrm{~min} \\
\text { 6. Particle size }\end{array}$ \\
\hline
\end{tabular}

Table 4. Evaluation methods on the heavy duty coatings.

\begin{tabular}{|c|c|c|}
\hline & Item & Condition \\
\hline $\begin{array}{l}\text { Basic } \\
\quad \text { properties }\end{array}$ & $\begin{array}{l}\text { Tensile property } \\
\text { Water absorption } \\
\text { Humidity permeability } \\
\text { Oxygen permeability }\end{array}$ & $\begin{array}{l}\text { Condition } \\
\text { ASTM D } 638 \text { : sample type } \mathrm{N} \text {, tensile rate }: 50 \mathrm{~mm} / \mathrm{min} \\
\text { Free film, increased weight ratio after } 1100 \mathrm{~h} \text { in tap water } \\
\text { Free film, } 100 \% \mathrm{RH} / 10 \% \mathrm{RH}, 40^{\circ} \mathrm{C} \\
\text { Free film, } 100 \% \mathrm{O}_{2} \text { gas, } \Delta P=1 \mathrm{~atm}, 40^{\circ} \mathrm{C}\end{array}$ \\
\hline $\begin{array}{l}\text { Mechanical } \\
\text { properties }\end{array}$ & $\begin{array}{l}\text { Impact resistance } \\
\text { Bendaility } \\
\text { Abrasion resistance } \\
\text { Adhesion strength }\end{array}$ & $\begin{array}{l}\text { ASTM G14; punch diameter : } 16 \mathrm{~mm} \phi \\
\text { DIN30671; } 3 \text { point bend beam, punch diameter }: 50 \mathrm{~mm} \phi \\
\text { Taber abrasion test; CS-17, weight loss after } 1000 \text { rotation (load : } 1 \mathrm{~kg} \text { ) } \\
\text { Pull off method; pull rate }: 10 \mathrm{~mm} / \mathrm{min} \text {, area }: 3.14 \mathrm{~cm}^{2} \text {, peeling; } 180^{\circ} \text { peel ( } 10 \mathrm{~mm} \text { width), } \\
\text { peel rate }: 10 \mathrm{~mm} / \mathrm{min}\end{array}$ \\
\hline $\begin{array}{l}\text { Corrosion } \\
\text { resistance }\end{array}$ & $\begin{array}{l}\text { Salt spray test } \\
\text { Salt water immersion } \\
\text { Dry/wet cycle test } \\
\text { Cathodic disbonding } \\
\text { Thermal gradient immersion }\end{array}$ & $\begin{array}{l}35^{\circ} \mathrm{C}, 5 \% \mathrm{NaCl} \text { spray, } 30 \text { days, with cross cut }\left(90^{\circ}\right) \\
3 \% \mathrm{NaCl} \text { immersion, } 30 \text { days, with cross cut }\left(90^{\circ}\right) \\
35^{\circ} \mathrm{C} \text {, artifical sea water immersion } 6 \mathrm{~h} / \mathrm{dry} 6 \mathrm{~h} 60 \text { cycles, with cross cut }\left(90^{\circ}\right) \\
\text { ASTM G8; initial holiday : } 5 \mathrm{~mm} \phi, 3 \% \mathrm{NaCl}, 20^{\circ} \mathrm{C}, 30 \text { days, } 60 \text { days, } \\
\text { Applied potential : }-1.5 \mathrm{~V}(v \mathrm{ss} \text {. SCE }) \\
\text { Coating side } 50^{\circ} \mathrm{C} 3 \% \mathrm{NaCl} / \text { steel side } 30^{\circ} \mathrm{C} \text { tap water, } 30 \text { days, } 60 \text { days }\end{array}$ \\
\hline $\begin{array}{l}\text { Weathering } \\
\text { resistance }\end{array}$ & Accelerated weathering test & Sunshine carbon arc weather-o-meter test $-8000 \mathrm{~h}$ \\
\hline
\end{tabular}


ンプルは，上铜极をオーブンで $260 \sim 280^{\circ} \mathrm{C} に$ 予熱後, 流動浴洁法により作製した。被覆鋼板サンプルにおいて は下地処理条作として涂乕型クロメート処理（クロム付 着里 $200 \sim 300 \mathrm{mg} / \mathrm{m}^{2}$ ) の効果についても検讨した。試 験内行を Table 4 にまとめる。また, 尖用特性の把握

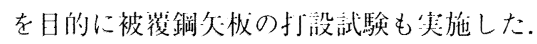

\section{4. 実験結果及び考察}

\section{$4 \cdot 1$ 各種防食材料の基本物性}

条種材料の被蕧基本物性を Table 5，6 ならびに Fig. 1, 2 に亦す.

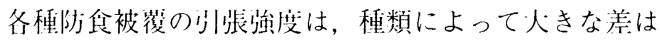

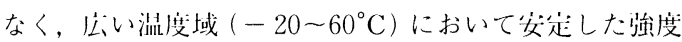
を们する。しかし，引梫帆びに関しては，ウレタンエラ ストマーならびにポリエチレン粉体は急激な变化を示さ

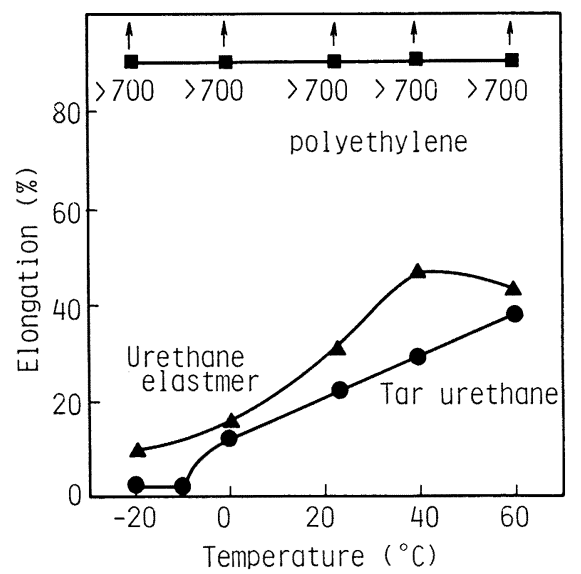

Fig. 1. Elongation of coating films and temperature.
ないが，タールウレタンは $0^{\circ} \mathrm{C}$ 以下で，伸び性が急激 に低下 (脆化) する。

また防食性能を左不する被覆の吸水率ならびに侩食性 物質の透過率は, ポリエチレン粉体では, 吸水率ならび に透過浢ともに極めて小さく，水に対する遮蔽性は極め て大きいが，腐食の関与物所の一つである酸素の透過率 が相対们に人きい。

ウレタンエラストマーならびにタールウレタンでは, ポリエチレン粉体に比べ吸水率が大きいが, 酸素透過摔 は極めて小さい.

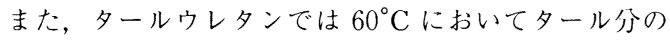
鼬水中への溶山が認められた。

\section{$4 \cdot 2$ 各種防食被覆の機械的特性}

各種防食被覆の機械的特性を Table 7, Fig. 3,4に 亦す，機械的特性は，特に衝繋性ならびに曲げ性におい て，被蕧材の種類により大きな差が恋められた。

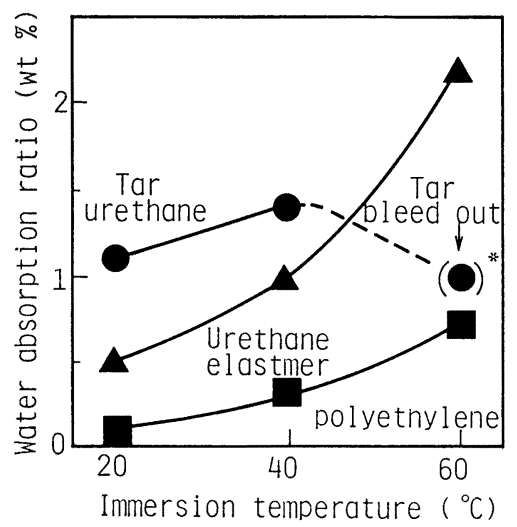

Tap water $1100 \mathrm{~h}$ immersion

Fig. 2. Water absorption of coatings and immersion temperature.

Table 5. Tensile strength and elongation on various anticorrosive coatings.

\begin{tabular}{|c|c|c|c|c|c|c|c|c|c|c|}
\hline \multirow{2}{*}{$\mathrm{C}_{\text {Coatings }}^{\text {Item }}$} & \multicolumn{5}{|c|}{ Tensile strength $\left(\mathrm{N} / \mathrm{mm}^{2}\right)$} & \multicolumn{5}{|c|}{ Elongation (\%) } \\
\hline & $-20^{\circ} \mathrm{C}$ & $0^{\circ} \mathrm{C}$ & $20^{\circ} \mathrm{C}$ & $40^{\circ} \mathrm{C}$ & $60^{\circ} \mathrm{C}$ & $-20^{\circ} \mathrm{C}$ & $0^{\circ} \mathrm{C}$ & $20^{\circ} \mathrm{C}$ & $40^{\circ} \mathrm{C}$ & $60^{\circ} \mathrm{C}$ \\
\hline $\begin{array}{l}\text { Tar urethane } \\
\text { Urethane elastmer } \\
\text { Polyethylene powder }\end{array}$ & $\begin{array}{l}26.0 \\
46.6 \\
24.0\end{array}$ & $\begin{array}{l}28.7 \\
34.0 \\
18.1\end{array}$ & $\begin{array}{l}12.3 \\
15.6 \\
11.5\end{array}$ & $\begin{array}{r}7.2 \\
10.7 \\
8.2\end{array}$ & $\begin{array}{l}3.7 \\
5.1 \\
6.0\end{array}$ & $\begin{array}{r}2 \\
10 \\
>700\end{array}$ & $\begin{array}{r}12 \\
16 \\
>700\end{array}$ & $\begin{array}{r}20 \\
30 \\
>700\end{array}$ & $\begin{array}{r}29 \\
67 \\
>700\end{array}$ & $\begin{array}{r}38 \\
43 \\
>700\end{array}$ \\
\hline
\end{tabular}

Table 6. Water absorption and permeability on various anticorrosive coatings.

\begin{tabular}{|c|c|c|c|c|c|}
\hline \multirow[b]{2}{*}{ Coatings } & \multicolumn{3}{|c|}{$\begin{array}{c}\text { Water absorption } \\
\left(\begin{array}{cc}1 & 100 \mathrm{~h}, \mathrm{wt} \% \\
( & ): \text { Saturated }\end{array}\right)\end{array}$} & \multirow{2}{*}{$\frac{\text { Water permeation coefficient }}{\left(\begin{array}{l}\mathrm{STP} \cdot \mathrm{cm}^{3} \cdot \mathrm{cm} \\
\mathrm{mmHg} \cdot \mathrm{cm}^{2} \cdot \mathrm{s}\end{array}\right)}$} & \multirow{2}{*}{$\frac{\begin{array}{c}\text { Oxygen gas permeation coefficient } \\
\left(\begin{array}{l}\mathrm{STP} \cdot \mathrm{cm}^{3} \cdot \mathrm{cm} \\
\mathrm{mmHg} \cdot \mathrm{cm}^{2} \cdot \mathrm{s}\end{array}\right)\end{array}}{40^{\circ} \mathrm{C}}$} \\
\hline & $23^{\circ} \mathrm{C}$ & $40^{\circ} \mathrm{C}$ & $60^{\circ} \mathrm{C}$ & & \\
\hline $\begin{array}{l}\text { Tar urethane } \\
\text { Urethane elastmer } \\
\text { Polyethylene powder }\end{array}$ & $\begin{array}{l}1.1 \\
0.5 \\
(0.1)\end{array}$ & $\begin{array}{l}1.4 \\
1.0 \\
(0.3)\end{array}$ & $\begin{array}{l}1.0 \\
2.3 \\
0.7\end{array}$ & $\begin{array}{l}1.06 \times 10^{-9} \\
9.32 \times 10^{-9} \\
6.40 \times 10^{-9}\end{array}$ & $\begin{array}{l}1.25 \times 10^{-11} \\
1.70 \times 10^{-11} \\
1.02 \times 10^{-9}\end{array}$ \\
\hline
\end{tabular}


Table 7. Mechanical properties on various anticorrosive coatings.

\begin{tabular}{|c|c|c|c|c|c|c|}
\hline \multirow[b]{2}{*}{ Coatings } & \multicolumn{3}{|c|}{$\begin{array}{l}\text { Initial adhesion strength } \\
\text { Urethane; pull off method }\left(\mathrm{N} / \mathrm{cm}^{2}\right)\end{array}$} & \multicolumn{2}{|c|}{ Polyethylene; peeling (N/cm) } & \multirow{2}{*}{$\begin{array}{l}\begin{array}{l}\text { Abrasion resistance } \\
\text { Taber abrasion test } \\
\text { CS-17 } 1000 \text { rotations }\end{array} \\
23^{\circ} \mathrm{C}\end{array}$} \\
\hline & $-20^{\circ} \mathrm{C}$ & $0^{\circ} \mathrm{C}$ & $20^{\circ} \mathrm{C}$ & $40^{\circ} \mathrm{C}$ & $60^{\circ} \mathrm{C}$ & \\
\hline $\begin{array}{l}\text { Tar urethane } \\
\text { Urethane elastmer } \\
\text { Polyethylene powder }\end{array}$ & $\begin{array}{l}710 \\
450 \\
260\end{array}$ & $\begin{array}{l}840 \\
540 \\
185\end{array}$ & $\begin{array}{r}1280 \\
\mathrm{~S}>1060 \\
90\end{array}$ & $\begin{array}{r}\mathrm{C}>670 \\
\mathrm{~S}>840 \\
70\end{array}$ & $\begin{array}{r}\mathrm{C}>270 \\
\mathrm{~S}>400 \\
25\end{array}$ & $\begin{array}{r}128 \mathrm{mg} \\
54 \mathrm{mg} \\
13 \mathrm{mg}\end{array}$ \\
\hline
\end{tabular}

S : Adhesive/Coating interfacial disbonding $\mathrm{C}$ : Cohesive destruction of the coating

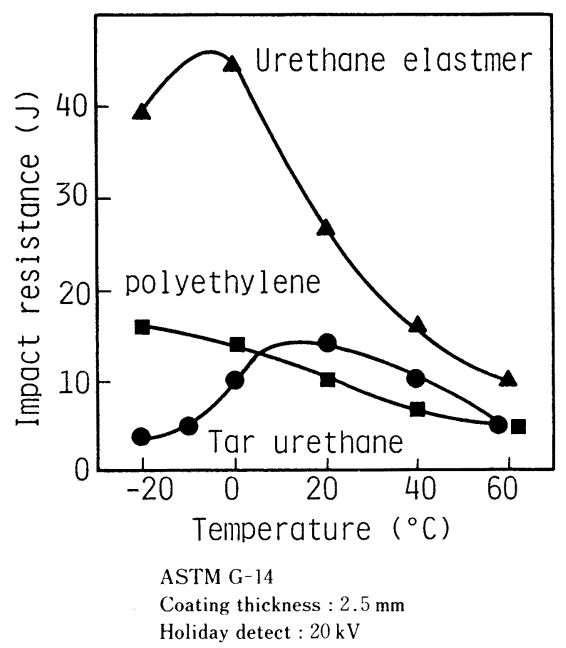

Fig. 3. Impact resistance of coatings and temperature.

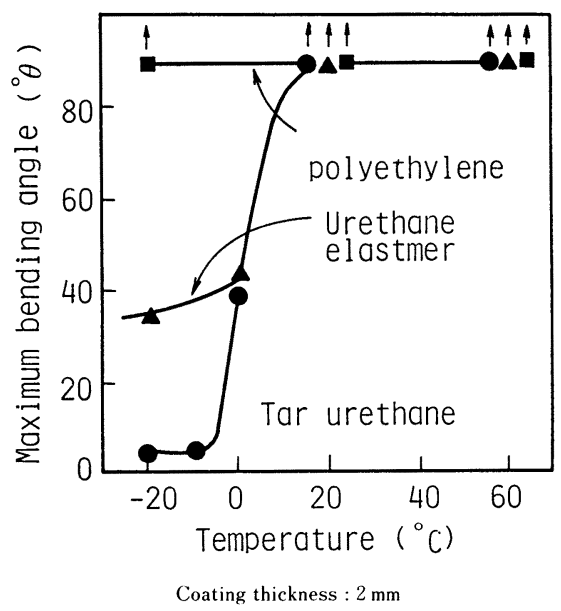

Fig. 4. Bendability of coatings and temperature.

耐衝撃性は, ウレタンエラストマー被覆が全温度域 $\left(ー 20 \sim 60^{\circ} \mathrm{C}\right)$ で優れた強度を示した。 ポリエチレン粉 体被覆は, 低密度ポリエチレンを使用しているためと考 えられるが, 衝撃力による塑性変形 (屽み) が大きく, 耐衝撃性に劣る。一力, ウレタンエラストマー被覆では,
エラストマー構造による弾性変形が作じており，舺衝撃 性に優れている。また，タールウレタン被復では，被膜 の引張試験において認められた脆化により， $0^{\circ} \mathrm{C}$ 以下で 被膜が脆性破壊する倾们があり，低温での䑧衝繋性は薯 しく劣る。

甪曲げ性においても，タールウレタンでは，舺衝繋性 と同様な傾问が認められ，低温特性に劣る。特に鋼の弾 性変形近傍でも $0^{\circ} \mathrm{C}$ 以下では脆性㴗れを牛じるため, 日本のように $0^{\circ} \mathrm{C}$ 以下になる川能性のある地域での鋼 材の重防食被覆としては適用しにくい材料であると考え られる。

\section{$4 \cdot 3$ 各種防食被覆の防食性}

各種防食被㠅の防食性检㣥紸果をTable 8 ならびに Fig. 5〜7 に示す.

鋼欠板や鋼管欠板などの土木建材の重防食被覆におい ては被覆の端而露出ならびに被膜欠绝の発生を考虑した 防食性（端而二次密着性：被覆材端面からの浸水による 密着低下幅が小さいこと) が要求される。この端陑二次 密着性において, ポリエチレン粉体被蕧は, 鋼材の高温 予熱を必要とし鋼表而の酸化が避けにくく，その性能が 少っている。この特性の们上には一般にクロメート処理 が存効であるが，クロメート処理を施してもウレタン系 被覆に劣っている。.-一力, ウレタン系被㠅では極めて高 い端面一次密着性を示す．特にウレタンエラストマー被 覆では，プライマー下地処理5)を適用しているため，ク ロメート下地処理を適用しなくてもこの特性は䟚好であ る (Fig. 5).

また，海洋環境で用いられる鋼材の防食法の中で，㴆 時海水中に浸漬された部位は，電気防食が極めて存効に 作用することが知られている。 そこで, 重防食被覆建材 においても，電気防食との併用が経济性ならびに防食性 に優れ，よく適用されている(すなわち電気防食の効果 が十分発揮されないとともに貝食速度が極めて大きい干 満帯抢よび飛沫帯を重防食被覆により防食し, 没水带は 電気防食を適用する防食法)。そのため, 重防食被蕧の 過防食電位に扔ける端酒二次密着性（耐陰極電解剝離 性)も重要である. 
Table 8. The change of electric resistance on various anticorrosive coatings after corossion test $\left(\Omega \mathrm{m}^{2}\right.$; coating thickness $2 \mathrm{~mm}$, test area $5 \times 5 \mathrm{~mm}$ ).

\begin{tabular}{|c|c|c|c|}
\hline Coatings & Initial & $\begin{array}{l}3 \% \mathrm{NaCl} \text { immerrsion test } \\
60^{\circ} \mathrm{C} 30 \text { days }\end{array}$ & $\begin{array}{l}\text { Thermal gradien test } \\
50^{\circ} \mathrm{C} / 30^{\circ} \mathrm{C} 30 \text { days }\end{array}$ \\
\hline $\begin{array}{l}\text { Tar urethane } \\
\text { Urethane elastmer } \\
\text { Polyethylene powder }\end{array}$ & $\begin{array}{l}4 \times 10^{8} \\
5 \times 10^{9} \\
>10^{10}\end{array}$ & $\begin{array}{l}1 \times 10^{8} \\
3 \times 10^{9} \\
5 \times 10^{9}\end{array}$ & $\begin{array}{l}2 \times 10^{8} \\
5 \times 10^{9} \\
1 \times 10^{10}\end{array}$ \\
\hline
\end{tabular}

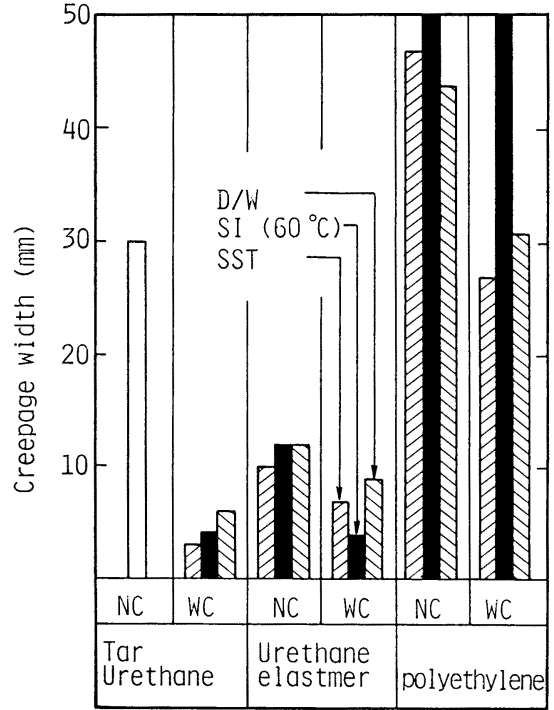

NC: Without chromate WC : With chromate D/W : Dry/Wet 60 cycles ( 30 days)

SI : $3 \%$ salt water immesion test 30 days SST : Salt Spray Test, 30 days

Fig. 5. Corrosion resistance properties and effect of chromate treatment for anticorrosive coatings.

この耐陰極電解虽離性においても, 各種防食被復は, 各種環境での端而二次密着性と同様な傾们を示して㧈り プライマー下地処理を存するウレタンエラストマー被㠅 がクロメート処理の有無にかかわらず極めて高い性能を 示している.

さらに，海洋構造物では，40〜50 年にも及ぶ产期の 防食性が要求され，重防食被覆には产期润にわたる絶䋨

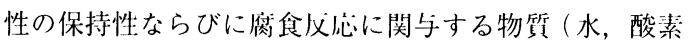
等) の遮断性が必要である.

これらの特性の少る被覀では，智期間のうちに被膜下 腐食が進行するとともに，それに伴うブリスタ一発生に よる被覆の破壊を生じ，防食性を期待できなくなる.

絶緣性については，今回検討の重防食被覆のいずれも $60^{\circ} \mathrm{C}$ の高温促進条件ならびに温度勾配促進条件下にお いて高い絶綄性を保持していることから問題はないと考 えられる.

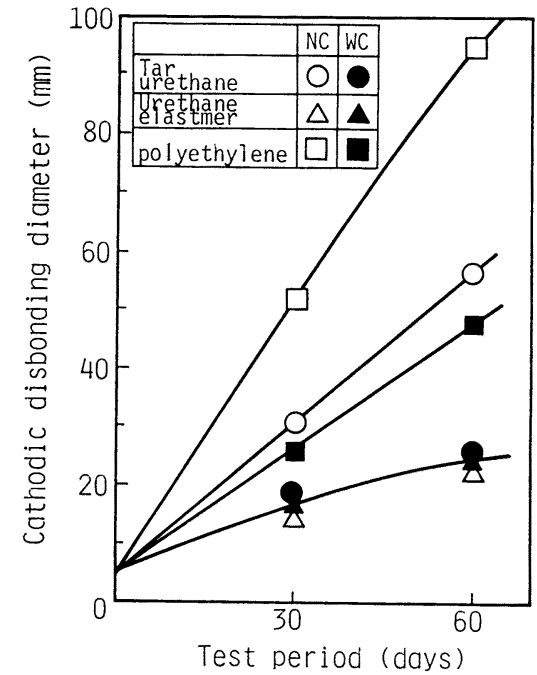

ASTM $\mathrm{G}^{-}-8$ : Initial holiday $5 \mathrm{~mm} \phi$

Fig. 6. Cathodic disbonding resistance of anticorrosive coatings with chromate (WC) and without chromate (NC).

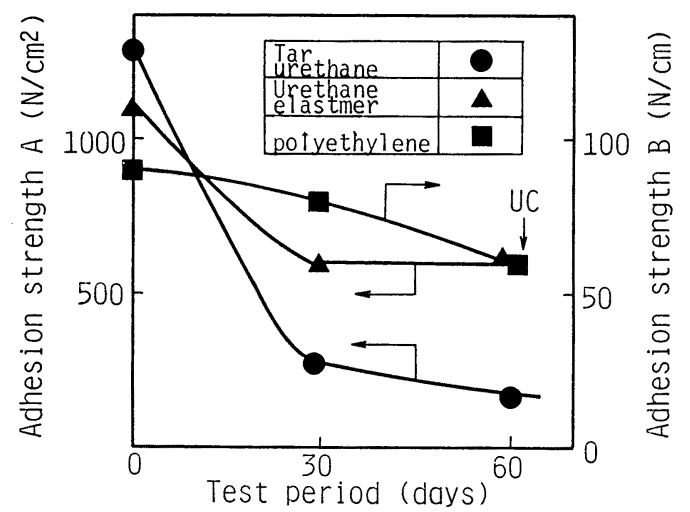

Thermal gradient $50^{\circ} \mathrm{C} / 30^{\circ} \mathrm{C}$

Adhesion strength $\mathrm{A}$ : Pull off method Adhesion strength $\mathrm{B}: 180^{\circ} \mathrm{C}$ peeling

UC : Underfilm Corrosion

Fig. 7. Result of thermal gradient test for anticorrosive coating with chromate. 
また，长期にわたる水・酸素の透過に対する抵抗性の 検澍法として, 近年温度勾配浸清 ${ }^{617)}$ による促進評価法 がよく用いられている。その原理は，被覆鋼材に扰いて， 被膜表面側が高温，鋼面側が低温になるような温度勾配 が你在するとき温度差に起因する水や酸素のケミカルポ テンシャルの差が推進力となって水や酸素の透過が非常 に促進される。このため実環境では数十年と考元られる 重防食被覆の柎ブリスター性を非常に短期䦔で評価する ことが川能である。試験結果を Fig. 7 に示す。ウレタ ンエラストマー被稪は，試験期間 30 日で若平の密着低 下を生じたが，それ以上の密着低下は進行せず，㢃好な 耐ブリス夕一性を有している。また，タールウレタン被 覆は，被覆が水分吸収により膨潤状態となり，突介世密 着力の測足に书いて被複の凝集破壊を示した。下地鋼面 の発錆は認められなかったが，吸水率の測定でもウレ夕 ンエラストマーより大きかったことからウレタンエラス トマー被覆より耐水性が劣ると考えられる。一方，ポリ エチレン被覆は密着力の低下は少ないものの，試験期間 60 日において下地鋼面に点錆が認められた。前述のよ うにポリエチレンは水分透過に対する遮断性には優れて いるが, 酸素の透過率は大きいことから被覆下腐食を発 生したと考えられ，この被覆下歷食においては水分の透 過ではなく酸素の透過が律速過程になっているものと考 えられる。

\section{$4 \cdot 4$ 各種防食被覆の耐候性}

各種防食被覆の耐候性に関して、サンシャインウェザ オメーターによる促進試験を实施し，その二次物性を検 討した。結果をFig. 8 に示す.

重防食被覆建材は层外で使用されるので，当然ながら 優れた耐候性が要求される。

3 種類すべての重防食被覆は, 比紊的早期（ウェザオ

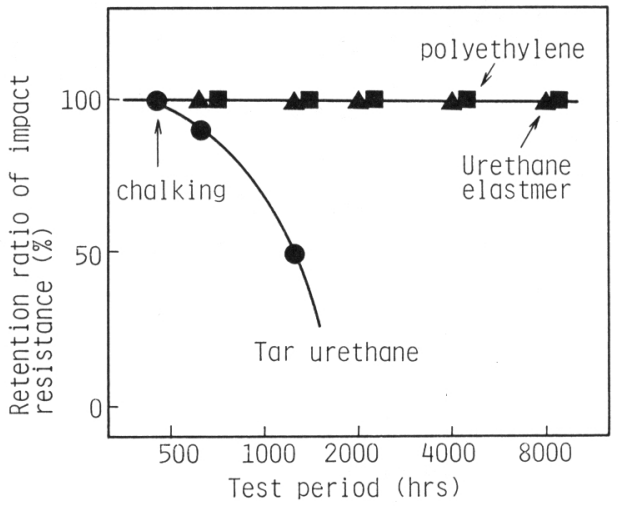

Carbon arc sunshine weather-o-meter

Fig. 8. Result of accelerated weathering test.
メーター照射時閌 500 h) にチョーキングを生じるが, その進行は遅く，数～十数 $\mu \mathrm{m} / 1000 \mathrm{~h}$ であり $2 \sim 3 \mathrm{~mm}$ の膜厚を存する重防食被覆の性能には問題とならない。

しかし, タールウレタン被覆ではチョーキングとは異 なる少化が生じていると考えられ，被覆の脆化傾们が認

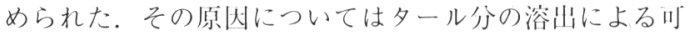
撓性の慗失などの叮能性が考えられるが, 洋練は不明で ある。

\section{$4 \cdot 5$ 実地打設性}

以上，ラボスケールでの検討結果について述べてきた が，实際にウレタンエラストマーを鋼矢极 $(400 \times 120$ $\mathrm{mm} \times 12 \mathrm{~m}$ 被覆部分 $6 \mathrm{~m}$ ）に膜厚 $2.0 \mathrm{~mm}$ になるように 被覆し, Fig. 9 に示寸土壤にバイブロハンマーによる打 設試験を実施した。打設後に引き抜いたウレタンエラス

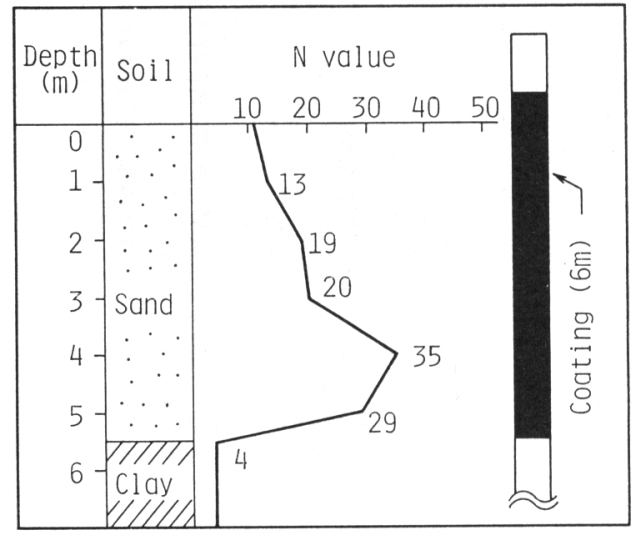

$\mathrm{N}$ value : Hammering count for $30 \mathrm{~cm}$ driving

Fig. 9. Soil condition on driving test for anticorrosive coated sheet piles.

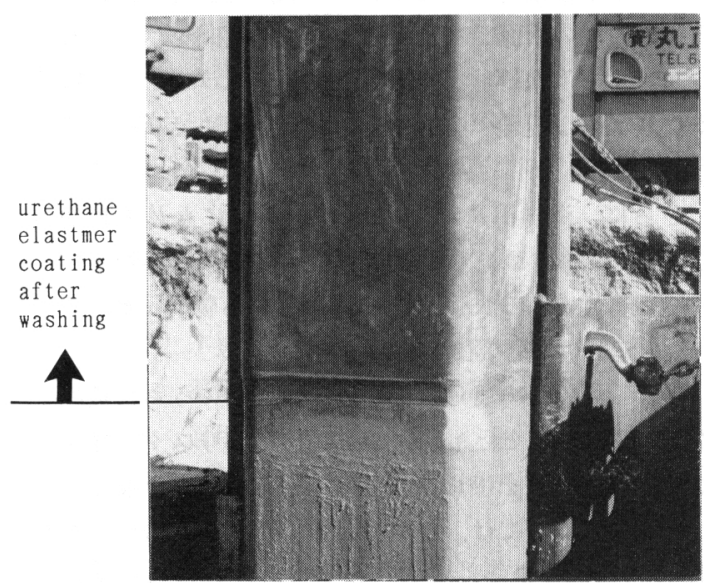

Photo. 1. Apearance of the urethane elastmer coated steel sheet pile after driving test. 
トマー被㠅鋼矢柲の外観状況を Photo. 1 に示す. 打設 作業による端面からの被膜剩離・損傷ならびに異常摩耗 は認められず健全であった。従って, ウレタンエラスト マー被覆は, 比較的硬い砂層である $\mathrm{N}$ 值 35 程度まで の地盤に対する打設にも耐え得る被覆の密着性・強度な らびに耐摩耗性を有している。

\section{5. 結}

\section{言}

海洋環境で多用される鋼矢板・鋼管矢板などの建材に 対するミルコーティングッ能な超厚膜型重防食被覆とし て, ウレタンエラストマー, タールウレタン, ポリエチ レン粉体の 3 種類の被覆材についてその性能を検剧し, 以下のことが判明した。

(1) ウレタンエラストマー被覆は, 機械的特性, 长期 防食性，ならびに舺候性などの諸特性のバランスに優れ 上記建材防食用の被覆材料として最も優れている.

(2)一方, タールウレタン被覆は, 低温や紫外線によ る脆化が問題である。またポリエチレン粉体被覆では予 熱時の鋼表而の酸化拀よび酸素の透過率が大きいことに よる防食性能に問題がある。
（３）ウレタンエラストマー被覆においては，二次密着 性に優れたプライマーを下地処理に適用して打り，クロ メート処理無しでも優れた防食性を示す。また，その工 ラストマー構造による弾性により優れた耐衝撃性を示 す.

(4)実地打設試験の紹果より』このウレタンエラスト マー被覆は比較的硬い砂層である $\mathrm{N}$ 值 35 程度までの 地盤に対する打込みにも十分耐之得る。

最後に, 本報告のウレタンエラストマー重防食被㠅建 材は，既に多くの海洋構造物に使用され，その防食性能 を発捙している.

\section{文献}

1) H. A. Humbi.f: Corrosion, 5 (1949), p. 292

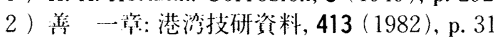

3 ）田中満生, 白石基雄: 防銷管理, 27 (1983), p. 312

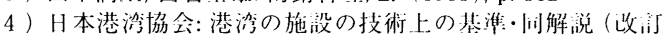
版) (1989), p. 238

5 ) 大北雅一, 新非哲三: 材料とプロセス, 1 (1988), p. 1658

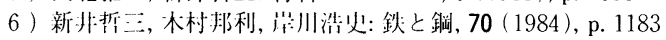

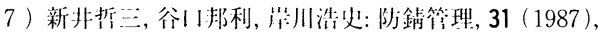
p. 398 